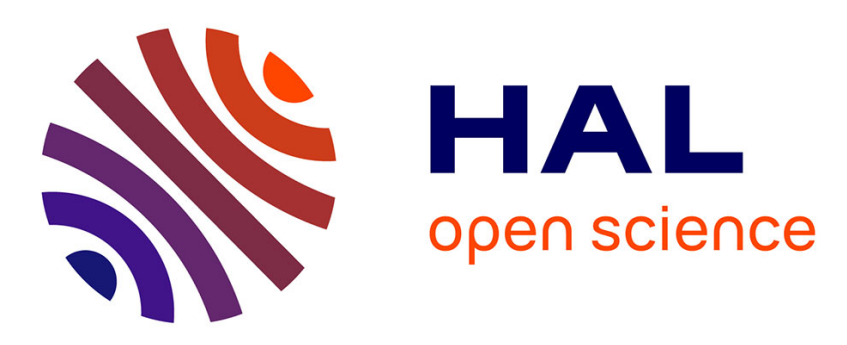

\title{
Diatom immigration drives biofilm recovery after chronic copper exposure
}

Soizic Morin, A.S. Lambert, Joan Artigas, Marina Coquery, S. Pesce

\section{To cite this version:}

Soizic Morin, A.S. Lambert, Joan Artigas, Marina Coquery, S. Pesce. Diatom immigration drives biofilm recovery after chronic copper exposure. Freshwater Biology, 2012, 57 (8), pp.1658-1666. 10.1111/j.1365-2427.2012.02827.x . hal-00871635

\section{HAL Id: hal-00871635 https://hal.science/hal-00871635}

Submitted on 10 Oct 2013

HAL is a multi-disciplinary open access archive for the deposit and dissemination of scientific research documents, whether they are published or not. The documents may come from teaching and research institutions in France or abroad, or from public or private research centers.
L'archive ouverte pluridisciplinaire HAL, est destinée au dépôt et à la diffusion de documents scientifiques de niveau recherche, publiés ou non, émanant des établissements d'enseignement et de recherche français ou étrangers, des laboratoires publics ou privés. 
This is the peer-reviewed version of the following article: Diatom immigration drives biofilm recovery after chronic copper

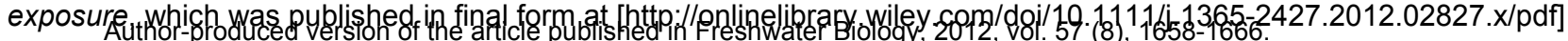

The original publication is available at http://onlinelibrary.wiley.com/doi/10.1111/j.1365-2427.2012.02827.x/abstract doi : 10.1111/j.1365-2427.2012.02827.x

1 Diatom immigration drives biofilm recovery after chronic copper exposure

2

3 Soizic Morin ${ }^{1}{ }^{*}$, Anne-Sophie Lambert ${ }^{2}$, Joan Artigas ${ }^{2}$, Marina Coquery², Stéphane Pesce ${ }^{2}$

$4 \quad{ }^{1}$ Irstea, UR REBX, 50 avenue de Verdun, 33612 Cestas cedex, France

5 * Corresponding author. Tel.: +33557892726; fax: +33557890801; e-mail address:

6 soizic.morin@irstea.fr (S. Morin)

$7 \quad 2$ Irstea, UR MALY, 3 bis quai Chauveau - CP 220, 69336 Lyon, France

8

9 Summary

1. The impact of immigration on the recovery of diatom assemblages after chronic exposure to copper was investigated in laboratory microcosms.

2. We examined the recovery trajectories of copper-contaminated biofilms after reducing copper stress and with or without the possibility of immigration from unimpaired communities.

3. The biofilms mixed with unimpaired communities returned to a "control" assemblage structure within 6 weeks, with recovery patterns depending on the endpoint considered (i.e. 2 weeks for relative abundances of diatom species but 6 weeks for total diatom biomass). In contrast, no recovery was observed in assemblages placed under control conditions without external immigrants.

4. Immigration has important effects on the recovery of quantitative and qualitative characteristics of biofilms. 
Author-produced version of the article published in Freshwater Biology, 2012, vol. 57 (8), 1658-1666.

The original publication is available at http://onlinelibrary.wiley.com/doi/10.1111/j.1365-2427.2012.02827.x/abstract doi : 10.1111/j.1365-2427.2012.02827.x

Keywords: Diatoms; Biofilm; Recovery; Copper; Immigration; Re-colonization

24 Introduction

25 In the early 90s, Stevenson \& Peterson $(1989,1991)$ studied the emigration and

26 immigration of benthic diatoms as determinants of periphytic communities in streams.

27 Since their work, the influence of immigration in freshwater benthic systems has mainly

28 been considered in relation to recovery following sharp changes in flow regime, i.e.

29 spate (Peterson \& Stevenson, 1992; Peterson, 1996; Stevenson, 1990) or episodes of

30 drought (Bambakidis, 2009; Benenati et al., 1998).

31 Translocation studies are increasingly used to assess the recovery potential of riverine

32 periphytic communities (biofilms). They are generally performed by transferring

33 biofilms from contaminated sites to uncontaminated sites upstream of the

34 contamination source (Dorigo et al., 2010; Morin et al., 2010a; Tolcach \& Gómez, 2002;

35 Rotter et al., 2011), but sometimes by transplanting contaminated communities to a

36 neighbouring river with similar environmental conditions (Ivorra et al., 1999).

Depending on the study, the time for full recovery of diatom assemblage structure has been estimated at from as little as two (Tolcach \& Gómez, 2002) to over nine weeks (Dorigo et al., 2010). The contribution of immigration to recovery after episodes of contamination is often questioned in translocation experiments, and ecotoxicological studies in general (e.g. Ivorra et al., 1999; Morin et al., 2010a). However, it remains

42 virtually impossible to discriminate between the effects of re-growth from remaining 43 viable cells and colonization by new immigrants. 
Author-produced version of the article published in Freshwater Biology, 2012, vol. 57 (8), 1658-1666.

The original publication is available at http://onlinelibrary.wiley.com/doi/10.1111/j.1365-2427.2012.02827.x/abstract doi : 10.1111/j.1365-2427.2012.02827.x

Here we performed an experimental study designed to assess the relative contribution

of drift to the recovery of diatom assemblages from copper exposure. A series of laboratory channels were used to grow biofilms under control and $\mathrm{Cu}$-contaminated conditions, prior to simulating the recovery of exposed assemblages with and without connectivity to unimpaired biofilms (i.e. allowing or not species immigration from a pristine community). Total diatom biomass and species relative abundances were monitored. In addition, a range of descriptors for assessing diatom population dynamics (daily rates of increase in diatom density, estimation of population growth) were determined in order to identify the ecological importance to recovery of immigration as distinct from re-growth from remnant cells.

\section{Methods}

\section{Experimental setup}

A suspension of natural biofilm from a pristine site located upstream of any pollution inputs in the Morcille river (Beaujolais region, Eastern France) was inoculated into 12 laboratory channels $(l \times w \times d=63 \times 11 \times 4 \mathrm{~cm})$. These channels were arranged in a blocked design into four sets of triplicate channels, two of which were grown under control conditions (see details in Lambert et al., 2012) while the other two were supplemented with copper at about $20 \mu \mathrm{g} \mathrm{L}-1$ for four weeks to obtain mature biofilms before the experiment. The channels were placed in parallel, at a light intensity of approximately 3500 lux (13:11 light:dark regime), under continuous water flow in recirculating mode (centrifugal pumps Rena Flow 600, 1.2L min-1). The copper concentrations used in this experiment were sufficient to produce effects on the 
Author-produced version of the article published in Freshwater Biology, 2012, vol. 57 (8), 1658-1666.

The original publication is available at http://onlinelibrary.wiley.com/doi/10.1111/j.1365-2427.2012.02827.x/abstract doi : 10.1111/j.1365-2427.2012.02827.x (such concentrations are occasionally measured downstream in the Morcille river: see Montuelle et al., 2010). In each channel, microscope glass slides were immersed to allow biofilm settlement and harmonize sampling conditions (similar substratum characteristics, constant surface area) throughout the experiment. The diatom assemblage inoculum was composed of at least 57 species, dominated by Nitzschia hantzschiana Rabenhorst (more than $80 \%$ relative abundance) followed by Achnanthidium minutissimum (Kützing) Czarnecki, Nitzschia capitellata Hustedt, Fragilaria capucina Desmazières var. capucina and Planothidium lanceolatum (Brébisson ex Kützing) Lange-Bertalot.

During the 6-weeks of recovery, four different treatments (each with three replicates) were tested (Fig. 1): I) Control treatment: a set of $n=3$ uncontaminated channels kept under uncontaminated water; II) $\mathrm{Cu}$ treatment: a set of $\mathrm{n}=3 \mathrm{Cu}$-contaminated channels kept exposed to about $20 \mu \mathrm{g} \mathrm{Cu} \mathrm{L}{ }^{-1}$; III) ExCu1 treatment: set of channels with biofilms grown under control conditions placed in the upstream half-section of the channels and biofilms grown under $\mathrm{Cu}$-contaminated conditions placed in the downstream section, filled with uncontaminated water; IV) ExCu2 treatment: set of biofilms grown under $\mathrm{Cu}$ contaminated conditions and filled with uncontaminated water. The ExCu1 and ExCu2 treatments were used to assess the recovery of diatom assemblages following a decrease in $\mathrm{Cu}$ exposure, with (ExCu1) or without (ExCu2) the possibility of diatom immigration from "control" assemblages to the impacted biofilms. 
Author-produced version of the article published in Freshwater Biology, 2012, vol. 57 (8), 1658-1666.

The original publication is available at http://onlinelibrary.wiley.com/doi/10.1111/j.1365-2427.2012.02827.x/abstract doi : 10.1111/j.1365-2427.2012.02827.x

\section{Water analyses}

All physicochemical parameters were monitored every two weeks, before and after the water was changed. For water changes, groundwater containing a very low $\mathrm{Cu}$ concentration $\left(<0.3 \mu \mathrm{g} \mathrm{L}^{-1}\right)$ was adjusted to the conductivity (i.e. $\left.600 \mu \mathrm{S} \mathrm{cm}-1\right)$ and nutrient concentrations (i.e. about $4 \mathrm{mg} \mathrm{Si} \mathrm{L}^{-1}, 5 \mathrm{mg} \mathrm{NO}_{3} \mathrm{~L}^{-1}, 0.05 \mathrm{mg} \mathrm{PO}_{4} \mathrm{~L}^{-1}$ ) of the sampling site. In the $\mathrm{Cu}$-contaminated channels, the water was supplemented with $\mathrm{CuSO}_{4}, 5 \mathrm{H}_{2} \mathrm{O}$ to obtain the nominal concentration of $20 \mu \mathrm{g} \mathrm{Cu} \mathrm{L}-1$.

Conductivity, $\mathrm{pH}$, temperature and oxygen concentration were measured in situ in each series of channels using suitable probes (WTW Meters, Weilheim, Germany). Water samples were taken to analyse nutrient content $\left(\mathrm{NO}_{2}, \mathrm{NO}_{3}, \mathrm{NH}_{4}, \mathrm{PO}_{4}, \mathrm{SiO}_{2}\right)$ and copper concentration. Nutrients were determined following French standards (AFNOR operating procedures and protocols). Dissolved $\mathrm{Cu}$ concentrations were analysed by ICP-MS (X Series II, Thermo Electron, UK) after filtration of a $30-\mathrm{mL}$ sample $(0.45 \mu \mathrm{m}$ PVDF, Whatman) and acidification with $0.5 \%$ nitric acid (Suprapur, Merck).

\section{Algal biomass and diatom analysis}

Biofilm samples (five glass slides) were collected in each replicate channel every two weeks from week 0 to week 6). In the ExCu1 treatment, channel samples were always collected in the "downstream" section, corresponding to biofilms previously exposed to copper (Fig. 1). The five slides were carefully scraped using a razor blade and the biofilms pooled and suspended in a standard volume of mineral water (Volvic, France). After homogenization of the resulting suspensions, aliquots were taken for fluorescence measurements (as a proxy of total algal biomass and of diatoms) and diatom taxonomic 
Author-produced version of the article published in Freshwater Biology, 2012, vol. 57 (8), 1658-1666.

The original publication is available at http://onlinelibrary.wiley.com/doi/10.1111/j.1365-2427.2012.02827.x/abstract doi : 10.1111/j.1365-2427.2012.02827.x

113 identification. Chlorophyll- $a$ fluorescence (Chl) emitted by diatoms was determined by

114 measurements using a PhytoPAM fluorometer (Walz, Effeltrich, Germany) equipped

115 with the PhytoEDF emitter-detector unit, performed on fresh material (as described in

116 Morin et al., 2010b). Data were then converted into $\mu \mathrm{g} \mathrm{Chl} \mathrm{cm}^{-2}$. Subsamples for diatom

117 identification were preserved in a formalin solution (4\%,v/v) and prepared according

118 to standard NF EN 13946. Briefly, organic matter was removed from the samples by

119 digestion in boiling hydrogen peroxide $\left(30 \% \mathrm{H}_{2} \mathrm{O}_{2}\right)$ followed by rinsing and successive

120 cycles of centrifugation and re-suspension in distilled water to remove any residual

121 peroxide. Clean material was then pipetted onto cover-slips and allowed to dry before

122 being mounted with a high refractive index mountant (Naphrax, Brunel Microscopes

123 Ltd, UK) for microscopic identification (x1000 magnification on a Leica DMRB

124 photomicroscope, Wetzlar, Germany). At least 400 individual diatoms were identified to

125 the lowest taxonomical level possible. The primary references used were Krammer \&

126 Lange-Bertalot (1986 - 1991) and the Diatoms of Europe series (A.R.G. Gantner Verlag

127 K.G, Ruggell). Relative abundance of the taxa identified was recorded (RA, in \%); when

128 deformed individuals were observed, their percentage was also determined.

Data treatment

131 Between-channel differences in physicochemical variables were tested with one-way

132 ANOVA and Tukey's post hoc HSD test using Statistica software (v5.1, StatSoft, France).

133 Linear mixed effects (LME) models were applied on the biological endpoints (total

134 diatom biomass, species richness, proportion of diatom deformities) to differentiate

135 between the effects of sampling date, treatment and their combination. Treatments and

136 dates were set as fixed effects and the samples taken from each artificial channel as

137 random effects. The analyses were performed using the nlme library implemented 
Author-produced version of the article published in Freshwater Biology, 2012, vol. 57 (8), 1658-1666.

The original publication is available at http://onlinelibrary.wiley.com/doi/10.1111/j.1365-2427.2012.02827.x/abstract doi : 10.1111/j.1365-2427.2012.02827.x

138 within the R environment (http://cran.r-project.org/).

139 Samples were ordinated by cluster analysis (Bray Curtis similarities) on the basis of

140 diatom species composition (PC-Ord v4.25, MjM Software, USA).

141 Diatom biomass values measured through fluorescence were used to convert taxon

142 counts (RA) into biomass values for the dominant species and abnormal valves

143 (expressed in $\mu \mathrm{g} \mathrm{Chl} \mathrm{cm}{ }^{-2}$ ). Based on these data, daily rates of increase ( $r$, in cell

144 doublings/day) during the exponential growth phase were calculated using the slope of

145 the line relating time and natural log biomass according to Wood et al. (2005).

146 Probability values of the linear regressions were calculated to determine whether

147 growth was significant, before investigating differences between treatments in the total

148 diatom biomass, dominant species found, and abnormal forms.

149 Two-week population growth (written as $\Delta \mathrm{pop}$ ) was determined for each treatment and

150 pair of consecutive sampling dates to estimate the impact of immigration. $\Delta$ pop was

151 determined by two factors: net fecundity (reproduction - death) and net immigration

152 (immigration - emigration). Net fecundity and immigration may differ according to

153 environmental conditions (Control vs. $\mathrm{Cu}$ ), thus ANOVA comparisons were only

154 performed for ExCu1 and ExCu2 to assess differences in net immigration. As they shared

155 a comparable contamination history, the differences in growth between ExCu1 and

156 ExCu2 corresponded to the immigration that occurred only in ExCu1 (immigration of

157 species from the "upstream" to the "downstream" slides, only the latter being sampled),

158 and were thus taken as an estimate of the potential influence of immigration.

159 
Author-produced version of the article published in Freshwater Biology, 2012, vol. 57 (8), 1658-1666.

The original publication is available at http://onlinelibrary.wiley.com/doi/10.1111/j.1365-2427.2012.02827.x/abstract doi : 10.1111/j.1365-2427.2012.02827.x

162

163

164

165

166

167

168

169

170

171

$172 \quad\left(4.2 \pm 0.9 \mu \mathrm{g} \mathrm{L}^{-1}\right)$

173

174 Diatom assemblages

175 Biomass of diatoms (Fig. 2) represented $87.5 \pm 0.5 \%$ of that of the overall phototrophic

176 assemblage in the Control channels, against $36.0 \pm 1.4 \%$ in $\mathrm{Cu}$-exposed channels.

177 Statistical differences in biomass were observed between treatments $(P<0.001)$, and a

178 significant increase with time was noted $(P=0.022$ in week $2, P<0.001$ in weeks 4 and 6$)$.

179 The proportion of diatoms increased in ExCu1 from $42.1 \pm 0.3 \%$ initially to $82.7 \pm 3.7 \%$ in

180 week 6, and reached a comparable diatom biomass to Controls $(P=0.058)$, whereas in

181 ExCu2 it was stable and significantly lower $(P<0.001)$, at $44.1 \pm 2.3 \%$ throughout the

182 experiment.

183 Species richness was significantly lower in the Controls than in the other treatments

$184(18 \pm 1$ vs $21 \pm 1, P=0.024)$, and tended to decrease over time (time effect on week $6,17 \pm 1$ 
Author-produced version of the article published in Freshwater Biology, 2012, vol. 57 (8), 1658-1666.

The original publication is available at http://onlinelibrary.wiley.com/doi/10.1111/j.1365-2427.2012.02827.x/abstract doi : 10.1111/j.1365-2427.2012.02827.x

185

186

187

188

189

190

191

192

193

194

195

196

197

198

199

200

201

202

203

204

205

206

species, $P<0.001$ ). The classification based on diatom species relative abundance (Fig. 3 ) clearly distinguished two sets of data:

1- Control and ExCu1 biofilms had comparable assemblages (upper branch of the cluster in Fig. 3); within this group, the samples were then classified according to sampling date.

The assemblage was composed mainly of Achnanthidium minutissimum (41 $\pm 2 \%$ ),

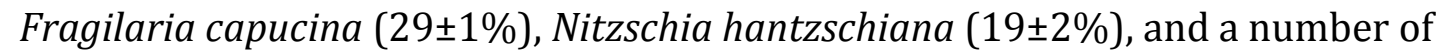
accompanying Achnanthidium species (A. affine [Grunow] Czarnecki, A. gracillimum [Meister] Lange-Bertalot and A. macrocephalum [Hustedt] Round \& Bukhtiyarova) accounting for about $5 \%$ of cumulated abundances.

2- $\mathrm{Cu}$ and $\mathrm{ExCu} 2$ communities composed the lower branch of the cluster, in which ExCu2 samples were all grouped together, except one (week 2, that was grouped with $\mathrm{Cu}$ samples). Relative abundance of species was less even, as Achnanthidium minutissimum $(53 \pm 4 \%)$ and Nitzschia hantzschiana $(30 \pm 4 \%)$ tended to dominate whereas Fragilaria capucina abundances markedly decreased $(6 \pm 1 \%)$. In the sub-cluster of ExCu2 samples (all but one, corresponding to week2), separation was due to a dominance of $A$. minutissimum $(67 \pm 4 \%)$ over $N$. hantzschiana $(14 \pm 1 \%)$ and F. capucina $(8 \pm 3 \%)$.

Initial percentages of diatom deformities were higher in $\mathrm{Cu}$ channels than in the Controls ( $p<0.001$, Fig. 2). Linear mixed effects analysis revealed significant treatment*date effects, as well as statistically higher abundances of deformed cells on week $6(p=0.003)$.

\section{Rates of increase in cell numbers and population dynamics}

Daily rates of increase (Fig. 4) in total diatom numbers were positive in all treatments, except for $\mathrm{Cu}$ channels where no significant growth was noticeable. Rates of increase $(r$ 
Author-produced version of the article published in Freshwater Biology, 2012, vol. 57 (8), 1658-1666.

The original publication is available at http://onlinelibrary.wiley.com/doi/10.1111/j.1365-2427.2012.02827.x/abstract doi : 10.1111/j.1365-2427.2012.02827.x

values) were highest in ExCu1 channels (three times the Control values) and were related mainly to increased growth of Achnanthidium minutissimum and Fragilaria

211 capucina populations. In ExCu2, Nitszchia hantzschiana declined (i.e. $r$ values were

212 negative); the highest $r$ values were recorded for $A$. minutissimum. This species grew

213 significantly in all channels, even Cu-contaminated ones. Values of $r$ for abnormal

214 diatom cells were positive in all Control, ExCu1 and ExCu2 channels, whereas their

215 quantity remained stable in Cu channels (no significant growth). This growth of

216 abnormal cells in Control, ExCu1 and ExCu2 channels led all the treatments to reach

217 similar proportions of diatom deformities at the end of the experiment, i.e. $2.6 \pm 0.1 \%$

218 (Fig. 2), which is significantly higher than the initial percentages detailed above.

219 Table 2 summarizes mean population growth parameters for all the treatments over the 220 experimental period. Subscripts in equations refer to the water conditions to indicate

221 that net fecundity (nF) of the standing crop, as well as immigration (I) and emigration

222 (E), differed according to environmental factors. No significant self-generated

223 detachment (Boulêtreau et al., 2006) was observed in the biofilms, suggesting that the

224 emigration component was probably comparable between treatments. Two-week $\Delta$ pop

225 was always lower under $\mathrm{Cu}$ conditions, agreeing with the $r$ calculations. Comparisons

226 between ExCu1 and ExCu2 population kinetics indicated statistical differences (linked to

227 significant immigration) for total diatom biomass and Fragilaria capucina (respectively

$228 P=0.006$ and $P<0.001 ; \mathrm{df}=23, \mathrm{~F}=9.22$ ). 
Author-produced version of the article published in Freshwater Biology, 2012, vol. 57 (8), 1658-1666.

The original publication is available at http://onlinelibrary.wiley.com/doi/10.1111/j.1365-2427.2012.02827.x/abstract doi : 10.1111/j.1365-2427.2012.02827.x

Discussion

Structural recovery after copper pressure ceased

234 Diatoms dominated in the Control channels but were less well represented in Cu-

235 exposed channels (Fig. 2). Chronic exposure to copper is known to cause a shift towards 236 dominance by green algae (Serra \& Guasch, 2009;Tlili et al., 2010): indeed, Cu samples 237 on week 0 were composed of $47 \pm 5 \%$ green algae. ExCu1 communities, due to increased 238 diatom cell doublings (Fig. 4), progressively reached the Control algal composition, 239 while ExCu2 communities remained close to $\mathrm{Cu}$-exposed composition.

240 Focussing on assemblage structure of diatoms in more detail, a selection of species less 241 susceptible to copper exposure occurred in the biofilms exposed to $\mathrm{Cu}$, i.e.

242 Achnanthidium minutissimum or Nitzschia capitellata (Duong et al., 2008; Morin et al., 243 2008b, 2012; Verb \& Vis, 2005). Figure 3 indicates that two weeks were more than 244 enough for ExCu1 assemblages to attain structure similar to the Controls, in accordance 245 with the most optimistic in situ translocation scenarios (Tolcach \& Gómez, 2002).

246 Without any external supply of colonists, $\mathrm{ExCu} 2$ assemblage structure tended to diverge 247 from the Cu-stressed state but did not reach the Control composition within the time248 course of the experiment. It followed a trajectory that was probably driven by in situ 249 differential reproduction of species selected by previous $\mathrm{Cu}$ exposure and subsequently 250 favoured by the new (uncontaminated) environmental conditions. The slower increase 251 in periphytic biomass in $\mathrm{ExCu} 2$ channels did not lead to such a strong decrease in local 252 contamination (i.e. $\mathrm{Cu}$ concentration in the biofilm) as in ExCu1 (Lambert et al., 2012), 253 thus maintaining somewhat greater toxic pressure. This could explain why the 254 succession trajectory of ExCu2 assemblages were mainly driven by a massive growth of 255 Achnanthidium minutissimum, a pioneer species (Medley \& Clements, 1998, Stevenson, 
Author-produced version of the article published in Freshwater Biology, 2012, vol. 57 (8), 1658-1666.

The original publication is available at http://onlinelibrary.wiley.com/doi/10.1111/j.1365-2427.2012.02827.x/abstract doi : 10.1111/j.1365-2427.2012.02827.x 1990) that is known to cope with metal contaminations (Morin et al., 2012), and to the decline of the copper-tolerant Nitzschia hantzschiana, which is probably less competitive than other species when water contamination ceases. Although deriving from a natural inoculum, the original assemblage was quite simple from the outset. The selection that occurred, along with the laboratory conditions used, meant that the assemblages studied here were closer to "model assemblages" than to the intricate structures that can be expected in nature. However, the trends observed here can be expected to be similar in more complex assemblages.

Interestingly, the percentage of diatom abnormalities remained fairly stable in the $\mathrm{ExCu} 2$ and $\mathrm{Cu}$ channels throughout the experiment. No significant increase in $r$ values was observed in $\mathrm{Cu}$ treatments (Fig. 4), suggesting that species affected by deformities were unable to reproduce, which is additional evidence for metal-induced genetic impairments (Falasco et al., 2009) which are likely to affect cell division (Schmid, 1984). Accrual of abnormal diatoms in ExCu2 (positive $r$ values) apparently contradicts this statement, but in this case can be compared to the clear kinetics of increasing deformities observed in Control and ExCu1 channels. Long-term culture under laboratory conditions has been shown to be responsible for cell deformations (Estes \& Dute, 1994; Torgan et al., 2006), which could explain the antagonistic results above. Nevertheless, the relative abundance of deformed diatoms had stabilized at about $2.6 \pm 0.1 \%$ by week 6 in all treatments.

\section{The role of immigration in diatom assemblage recovery}

It is almost impossible to distinguish between biotic and abiotic drivers in in situ experiments, but the abiotic drivers are generally considered as the major structuring 
Author-produced version of the article published in Freshwater Biology, 2012, vol. 57 (8), 1658-1666.

The original publication is available at http://onlinelibrary.wiley.com/doi/10.1111/j.1365-2427.2012.02827.x/abstract doi : 10.1111/j.1365-2427.2012.02827.x

components for natural communities (Sabater, 2009; Stevenson et al., 1996). In this

respect, biofilm recovery after toxicant reduction would result in a rearrangement in the

\section{3}

abundances of the remaining viable organisms (differential re-growth), whereas re-

colonization by upstream drift would rebuild an assemblage comprising those taxa that coped with the toxic stress plus immigrants. The residual biofilm including the surviving species would probably make the surface rougher and stickier than bare surfaces, and thus produce autogenic habitats favouring quicker re-colonization (Peterson et al., 1990). Moreover, the initially dominant species may enhance the ultimate development of late-successional species through facilitation (M. Bottin, pers. comm.).

In this study, we differentiated between the effects of a reduction in toxic stress and of 291 inputs of immigrants on the recovery process. Whatever the treatment (ExCu1, ExCu2),

292 the biofilms remaining after one month of $\mathrm{Cu}$ exposure contained enough viable 293 organisms to ensure there was no lag time in re-growth (data not shown). We found 294 clear differential trajectories from previously-exposed to unexposed diatom assemblage 295 structure in the ExCu1 and ExCu2 channels. In ExCu1, connection with unstressed 296 assemblages led to extremely rapid recovery. Conversely, recovery was delayed for 297 ExCu2 biofilms, which were still unable to attain a comparable diatom species 298 composition to Control biofilms even after 6 weeks under uncontaminated conditions. 299 Iserentant \& Blancke (1986) attributed changes in diatom assemblages after 300 transplantation to differential development/proliferation of the species that had already 301 settled. However, the quick recovery observed here of ExCu1 in terms of species 302 composition (within 2 weeks for diatom species relative abundances and 6 weeks for 303 diatoms chlorophyll $a$ ) demonstrates that immigration is important in the dynamics of 304 recovery. The role of species drift in recovery thus has to be considered, even if the 305 present very optimistic scenario probably resulted from the experimental design 
Author-produced version of the article published in Freshwater Biology, 2012, vol. 57 (8), 1658-1666.

The original publication is available at http://onlinelibrary.wiley.com/doi/10.1111/j.1365-2427.2012.02827.x/abstract doi : 10.1111/j.1365-2427.2012.02827.x

306

promoting dispersal and high connectivity (the proximity and high density of potential immigrants, very few water renewals, and intermediate water flow) enhancing potential immigration and subsequent algal succession (McCormick \& Stevenson, 1991; Rolland et al., 1997; Stevenson, 1983).

Higher reproduction rates in Control and ExCu1 channels can be inferred from increased silica consumption (Table 1). In situ reproduction of immigrants, although not easily measurable, is assumed to have substantially contributed to the above-mentioned recovery process. Indeed, biofilm diatoms show rapid reproduction (Baars, 1983; Morin et al., 2008a), resulting in an increase in the density of the newly-introduced organisms. Studies on interspecific variation in diatom immigration (Stevenson \& Peterson, 1991) indicated that Achnanthidium minutissimum immigration was double that for Fragilaria species; thus the massive growth of $F$. capucina in ExCu1 probably resulted from immigration and subsequent reproduction of highly-productive individuals originating from unimpaired biofilms. Ultimately, immigration and in situ reproduction of both persistent and re-colonizing species, although undistinguishable, play a major role in periphytic recovery after exposure to copper pollution.

\section{Ecological importance of preserving longitudinal connectivity in streams}

Current freshwater management plans (e.g. EU Water Framework Directive 2000/60/EC-, EU River Basin Management Plans, or Wenger, 2002) underline the importance of preserving river corridors as major "monitoring tools" for ecological restoration of freshwater hydroecosystems. Indeed, the proximity of unimpacted areas within catchments is believed to increase effective recovery of connected impaired sites. In this study, we indirectly assessed the gain in remediation efforts by characterizing the 
Author-produced version of the article published in Freshwater Biology, 2012, vol. 57 (8), 1658-1666.

The original publication is available at http://onlinelibrary.wiley.com/doi/10.1111/j.1365-2427.2012.02827.x/abstract doi : 10.1111/j.1365-2427.2012.02827.x

differential recovery of diatom assemblages (ExCu1 and ExCu2) after a chronic exposure to copper. Water contamination by micropollutants is recognized as a major issue in the EU, and our results support the qualitative importance of maintaining river corridors.

Overall, both immigration and in situ reproduction, although undistinguishable, enhanced periphytic recovery after exposure to copper pollution (ExCu1 treatment). In the wider perspective of restoring ecosystem integrity, maintaining intact reaches upstream would maximize the potential for downstream sites to recover from past contamination or after unexpected toxicant releases.

The findings reported here also demonstrated that diatom assemblages can recover largely by propagule immigration and in situ reproduction of recolonizing species. As might be expected, the immigrants here were species known as pioneers that are resistant to disturbances (e.g. Achnanthidium minutissimum; Peterson \& Stevenson, 1992) and common in the upstream site from which they originated (Morin et al., 2010a, Roubeix et al., 2011). These results could also highlight risks of high dispersability and potential to establish of undesirable diatoms, such as invasive species that immigrate readily, grow quickly and are highly competitive (Keller \& Lodge, 2009; Friberg et al., 2011). In a context of global change, such exotic species could be favoured by multiple stresses reinforced by environmental warming, and consequently outcompete or even replace native species (Coste \& Ector, 2000).

\section{Acknowledgments}

The authors thank Bernard Motte and Christophe Rosy for technical support, the Irstea's Water Chemistry Laboratory (LAMA) for physicochemical data, Hélène Sanejouand for nutrient analysis, and Josiane Gahou and Eloïse Vray for copper analysis. Prof. Alan 
Author-produced version of the article published in Freshwater Biology, 2012, vol. 57 (8), 1658-1666.

The original publication is available at http://onlinelibrary.wiley.com/doi/10.1111/j.1365-2427.2012.02827.x/abstract doi : 10.1111/j.1365-2427.2012.02827.x

354 Hildrew is acknowledged for his contributions that substantially improved the

355

manuscript.

This project was supported by funding from the French National Office for the Aquatic Environment (ONEMA).

\section{References}

Baars, J.W. (1983) Autoecological investigations on freshwater diatoms. 1. Generation times of some species. Archiv für Hydrobiologie - Supplement, 67, 11-18.

Bambakidis, T. (2009) Changes in benthic algal community structure following an unpredictable stream-wide desiccation event, Master of Science (MS), Bowling Green State University, Biological Sciences.

Benenati, P.L., Shannon, J.P. \& Blinn, D.W. (1998) Desiccation and recolonization of phytobenthos in a regulated desert river: Colorado River at Lees Ferry, Arizona, USA. Regulated Rivers: Research \& Management, 14, 519-532.

Boulêtreau, S., Garabétian, F., Sauvage, S. \& Sánchez-Pérez, J.-M. (2006) Assessing the importance of a self-generated detachment process in river biofilm models. Freshwater Biology, 51, 901-912.

Coste, M. \& Ector, L. (2000) Diatomées invasives exotiques ou rares en France: principales observations effectuées au cours des dernières décennies. Systematics and Geography of Plants, 70, 373-400.

Dorigo, U., Berard, A., Rimet, F., Bouchez, A. \& Montuelle, B. (2010) In situ assessment of periphyton recovery in a river contaminated by pesticides. Aquatic Toxicology, 98, 396-406.

Duong, T.T., Morin, S., Herlory, O., Feurtet-Mazel, A., Coste, M. \& Boudou, A. (2008) Seasonal effects of cadmium accumulation in periphytic diatom communities of freshwater biofilms. Aquatic Toxicology, 90, 19-28.

Estes, A. \& Dute, R.R. (1994) Valve abnormalities in diatom clones maintained in longterm culture. Diatom Research, 9, 249-258.

Falasco, E., Bona, F., Badino, G., Hoffmann, L. \& Ector, L. (2009) Diatom teratological forms and environmental alterations: a review. Hydrobiologia, 623, 1-35. 
Author-produced version of the article published in Freshwater Biology, 2012, vol. 57 (8), 1658-1666.

The original publication is available at http://onlinelibrary.wiley.com/doi/10.1111/j.1365-2427.2012.02827.x/abstract

doi : 10.1111/j.1365-2427.2012.02827.x

Friberg, N., Bonada, N., Bradley, D.C., Dunbar, M.J., Edwards, F.K., Grey, J., Hayes, R.B., Hildrew, A.G., Lamouroux, N., Trimmer, M. \& Woodward, G. (2011) Biomonitoring of human impacts in freshwater ecosystems: The Good, the Bad and the Ugly. In: Advances in Ecological Research. (Ed W. Guy), pp. 1-68. Academic Press.

Iserentant, R. \& Blancke, D. (1986) A transplantation experiment in running water to measure the response rate of diatoms to changes in water quality. In: Proceedings of the Eighth International Diatom Symposium. (Ed M. Ricard), pp. 347-354. Koeltz Scientific Books, Koenigstein.

Ivorra, N., Hettelaar, J., Tubbing, G.M.J., Kraak, M.H.S., Sabater, S. \& Admiraal, W. (1999) Translocation of microbenthic algal assemblages used for in situ analysis of metal pollution in rivers. Archives of Environmental Contamination and Toxicology, 37, 19-28.

Keller, R.P. \& Lodge, D.M. (2009) Invasive Species. In: Encyclopedia of Inland Waters. (Ed G.E. Likens), pp. 92-99. Academic Press, Oxford.

Krammer, K. \& Lange-Bertalot, H. (1986 - 1991) Bacillariophyceae 1. Teil: Naviculaceae. 876 p.; 2. Teil: Bacillariaceae, Epithemiaceae, Surirellaceae, 596 p.; 3. Teil: Centrales, Fragilariaceae, Eunotiaceae, 576 p.; 4. Teil: Achnanthaceae. Kritische Ergänzungen zu Navicula (Lineolatae) und Gomphonema. 437 p., G. Fischer Verlag., Stuttgart.

Lambert, A.-S., Morin, S., Artigas, J., Volat, B., Coquery, M., Neyra, M. \& Pesce, S. (2012) Structural and functional recovery of microbial biofilms after a decrease in copper exposure: Influence of the presence of pristine communities. Aquatic Toxicology, 109, 118-126.

McCormick, P.V. \& Stevenson, R.J. (1991) Mechanisms of benthic algal succession in lotic environments. Ecology, 72, 1835-1848.

Medley, C.N. \& Clements, W.H. (1998) Responses of diatom communities to heavy metals in streams: The influence of longitudinal variation. Ecological Applications, 8, 631-644.

Montuelle, B., Dorigo, U., Bérard, A., Volat, B., Bouchez, A., Tlili, A., Gouy, V. \& Pesce, S. (2010) The periphyton as a multimetric bioindicator for assessing the impact of land use on rivers: an overview of the Ardières-Morcille experimental watershed (France). Hydrobiologia, 1-19. 
Author-produced version of the article published in Freshwater Biology, 2012, vol. 57 (8), 1658-1666.

The original publication is available at http://onlinelibrary.wiley.com/doi/10.1111/j.1365-2427.2012.02827.x/abstract doi : 10.1111/j.1365-2427.2012.02827.x

Morin, S., Cordonier, A., Lavoie, I., Arini, A., Blanco, S., Duong, T.T., Tornés, E., Bonet, B., Corcoll, N., Faggiano, L., Laviale, M., Pérès, F., Becares, E., Coste, M., Feurtet-Mazel, A., Fortin, C., Guasch, H. \& Sabater, S. (2012) Consistency in diatom response to metal-contaminated environments. In: Handbook of Environmental Chemistry. (Eds H. Guasch, A. Ginebreda \& A. Geiszinger), pp. 117-146, Vol. Emerging and Priority Pollutants in Rivers. Springer, Heidelberg.

Morin, S., Coste, M. \& Delmas, F. (2008a) A comparison of specific growth rates of periphytic diatoms of varying cell size under laboratory and field conditions. Hydrobiologia, 614, 285-297.

Morin, S., Coste, M. \& Delmas, F. (2008b) From field studies to laboratory experiments for assessing the influence of metal contamination on relative specific growth rates of periphytic diatoms. In: Heavy metal pollution. (Eds S.E. Brown \& W.C. Welton), pp. 137-155. Nova Science, New York.

Morin, S., Pesce, S., Tlili, A., Coste, M. \& Montuelle, B. (2010a) Recovery potential of periphytic communities in a river impacted by a vineyard watershed. Ecological Indicators, 10, 419-426.

Morin, S., Proia, L., Ricart, M., Bonnineau, C., Geiszinger, A., Ricciardi, F., Guasch, H., Romaní, A. \& Sabater, S. (2010b) Effects of a bactericide on the structure and survival of benthic diatom communities. Vie et Milieu (Life and Environment), 60, 109-116.

Peterson, C.G. (1996) Mechanisms of lotic microalgal colonization following spaceclearing disturbances acting at different spatial scales. Oikos, 77, 417-435.

Peterson, C.G., Hoagland, K.D. \& Stevenson, R.J. (1990) Timing of wave disturbance and the resistance and recovery of a freshwater epilithic microalgal community. Journal of the North American Benthological Society, 9, 54-67.

Peterson, C.G. \& Stevenson, R.J. (1992) Resistance and resilience of lotic algal communities: Importance of disturbance timing and current. Ecology, 73, 14451461.

Rolland, T., Fayolle, S., Cazaubon, A. \& Pagnetti, S. (1997) Methodical approach to distribution of epilithic and drifting algae communities in a French subalpine river: Inferences on water quality assessment. Aquatic Sciences - Research Across Boundaries, 59, 57-73. 
Author-produced version of the article published in Freshwater Biology, 2012, vol. 57 (8), 1658-1666.

The original publication is available at http://onlinelibrary.wiley.com/doi/10.1111/j.1365-2427.2012.02827.x/abstract doi : 10.1111/j.1365-2427.2012.02827.x

Rotter, S., Sans-Piché, F., Streck, G., Altenburger, R. \& Schmitt-Jansen, M. (2011) Active bio-monitoring of contamination in aquatic systems--An in situ translocation experiment applying the PICT concept. Aquatic Toxicology, 101, 228-236.

Roubeix, V., Mazzella, N., Schouler, L., Fauvelle, V., Morin, S., Coste, M., Delmas, F. \& Margoum, C. (2011) Variations of periphytic diatom sensitivity to the herbicide diuron and relation to species distribution in a contamination gradient: implications for biomonitoring. Journal of Environmental Monitoring, 13, 17681774.

Sabater, S. (2009) Diatoms. In: Encyclopedia of Inland Waters. (Ed G.E. Likens), pp. 149156. Elsevier.

Schmid, A.M.M. (1984) Wall morphogenesis in Thalassiosira eccentrica: comparison of auxospore formation and the effect of MT-inhibitors. In: Proceedings of the 7th International Diatom Symposium. (Ed D.G. Mann), pp. 47-70. Koeltz, Koenigstein.

Serra, A. \& Guasch, H. (2009) Effects of chronic copper exposure on fluvial systems: Linking structural and physiological changes of fluvial biofilms with the instream copper retention. Science of the Total Environment, 407, 5274-5282.

Stevenson, R.J. (1983) Effects of current and conditions simulating autogenically changing microhabitats on benthic diatom immigration. Ecology, 64, 1514-1524.

Stevenson, R.J. (1990) Benthic algal community dynamics in a stream during and after a spate. Journal of the North American Benthological Society, 9, 277-288.

Stevenson, R.J., Bothwell, M.L. \& Lowe, R.L. (1996) Algal ecology: Freshwater benthic ecosystems. Academic Press, Inc. San Diego, CA.

Stevenson, R.J. \& Peterson, C.G. (1989) Variation in benthic diatom (Bacillariophyceae) immigration with habitat characteristics and cell morphology. Journal of Phycology, 25, 120-129.

Stevenson, R.J. \& Peterson, C.G. (1991) Emigration and immigration can be important determinants of benthic diatom assemblages in streams. Freshwater Biology, 26, 279-294.

Tlili, A., Bérard, A., Roulier, J.-L., Volat, B. \& Montuelle, B. (2010) $\mathrm{PO}_{4}{ }^{3-}$ dependence of the tolerance of autotrophic and heterotrophic biofilm communities to copper and diuron. Aquatic Toxicology, 98, 165-177. 
Author-produced version of the article published in Freshwater Biology, 2012, vol. 57 (8), 1658-1666.

The original publication is available at http://onlinelibrary.wiley.com/doi/10.1111/j.1365-2427.2012.02827.x/abstract doi : 10.1111/j.1365-2427.2012.02827.x

Tolcach, E.R. \& Gómez, N. (2002) The effect of translocation of microbenthic communities in a polluted lowland stream. Verhandlungen Internationale Vereinigung Limnologie, 28, 254-258.

Torgan, L.C., Vieira, A.A.H., Giroldo, D. \& dos Santos, C.B. (2006) Morphological irregularity and small cell size in Thalassiosira duostra maintained in culture. In: Proceedings of the 18th International Diatom Symposium. (Ed A. Witkowski), pp. 407-416. Biopress Ltd., Bristol, UK.

Verb, R.G. \& Vis, M.L. (2005) Periphyton assemblages as bioindicators of mine-drainage in unglaciated western allegheny plateau lotic systems. Water, Air, and Soil Pollution, 161, 227-265.

Wenger, E. (2002) Guidelines for the constitution of ecological river networks. In: Nature and Environment Series, $n^{\circ} 129$. (Eds Council of Europe).

Wood, A.M., Everroad, R.C. \& Wingard, L.M. (2005) Measuring growth rates in microalgal cultures. In: Algal culturing techniques. (Ed R.A. Anderson), pp. 269-285. Phycological Society of America. 
Author-produced version of the article published in Freshwater Biology, 2012, vol. 57 (8), 1658-1666.

The original publication is available at http://onlinelibrary.wiley.com/doi/10.1111/j.1365-2427.2012.02827.x/abstract doi : 10.1111/j.1365-2427.2012.02827.x

Table 2: Mean $( \pm$ SE) values of 2-week variations in population and the corresponding formula of the $\Delta$ pop. $\Delta$ pop $=$ nF (net fecundity: reproduction - death) + I (immigration) - E (emigration). Letters in subscript refer to specific environmental conditions (CC: Control conditions; CU: Copper conditions; EX: ExCu1 and 2 conditions). $\mathrm{I}_{\mathrm{EX}}$ values in italics are non-significant. NHAN: Nitzschia hantzschiana, ADMI: Achnanthidium minutissimum, FCAP: Fragilaria capucina.

Table 1: Mean values $( \pm S E, n=3$ ) of physicochemical parameters of the water in the four series of channels, determined during the 6-week recovery period. Letters in superscript following $\mathrm{SiO}_{2}$ and Cu values indicate statistical differences between treatments (Tukey's HSD test; $P<0.01$ ).

\begin{tabular}{lcccc}
\hline & Control & Ex-Cu1 & Ex-Cu2 & $\mathrm{Cu}$ \\
\hline Conductivity $\left(\mu \mathrm{S} \mathrm{cm}^{-1}\right)$ & $106 \pm 12$ & $97 \pm 11$ & $99 \pm 11$ & $106 \pm 12$ \\
$\mathrm{O}_{2}\left(\mathrm{mg} \mathrm{L}^{-1}\right)$ & $7.9 \pm 0.6$ & $8.0 \pm 0.7$ & $8.4 \pm 0.8$ & $7.9 \pm 0.8$ \\
$\mathrm{pH}$ & $7.9 \pm 0.1$ & $7.9 \pm 0.1$ & $7.8 \pm 0.1$ & $7.8 \pm 0.1$ \\
$\mathrm{Temperature}\left({ }^{\circ} \mathrm{C}\right)$ & $20.6 \pm 0.4$ & $21.2 \pm 0.5$ & $20.9 \pm 0.5$ & $20.7 \pm 0.4$ \\
$\mathrm{NH}_{4}\left(\mu \mathrm{g} \mathrm{L}^{-1}\right)$ & $17.4 \pm 2.8$ & $17.0 \pm 3.3$ & $20.3 \pm 5.4$ & $18.7 \pm 4.1$ \\
$\mathrm{NO}_{2}\left(\mu \mathrm{g} \mathrm{L}^{-1}\right)$ & $23.1 \pm 4.9$ & $30.3 \pm 7.2$ & $41.7 \pm 7.2$ & $41.4 \pm 8.0$ \\
$\mathrm{NO}_{3}\left(\mathrm{mg} \mathrm{L}^{-1}\right)$ & $2.3 \pm 0.7$ & $2.6 \pm 0.8$ & $2.6 \pm 0.8$ & $2.3 \pm 0.7$ \\
$\mathrm{PO}_{4}\left(\mu \mathrm{g} \mathrm{L}^{-1}\right)$ & $52.9 \pm 16.3$ & $78.3 \pm 14.3$ & $63.3 \pm 18.7$ & $60.0 \pm 6.7$ \\
$\mathrm{SiO}_{2}\left(\mathrm{mg} \mathrm{L}^{-1}\right)$ & $2.1 \pm 0.6^{\mathrm{a}}$ & $4.8 \pm 0.5^{\mathrm{a}, \mathrm{b}}$ & $6.9 \pm 1.3^{\mathrm{b}}$ & $7.0 \pm 1.3^{\mathrm{b}}$ \\
$\mathrm{Cu}\left(\mu \mathrm{g} \mathrm{L}^{-1}\right)$ & $1.4 \pm 0.5^{\mathrm{a}}$ & $3.4 \pm 1.2^{\mathrm{a}}$ & $4.9 \pm 1.6^{\mathrm{a}}$ & $16.6 \pm 1.4^{\mathrm{b}}$
\end{tabular}

\begin{tabular}{lccccc}
\hline Two-week $\Delta$ pop $\left(\mu \mathrm{gChl} \mathrm{cm}{ }^{-2}\right)$ & Control & $\mathrm{Cu}$ & ExCu1 & ExCu2 & Immigration \\
\hline Equation & $\mathrm{nF}_{\mathrm{CC}}-\mathrm{E}_{\mathrm{CC}}$ & $\mathrm{nF}_{\mathrm{CU}}-\mathrm{E}_{\mathrm{CU}}$ & $\mathrm{nF}_{\mathrm{EX}}+\mathrm{I}_{\mathrm{Ex}}-\mathrm{E}_{\mathrm{Ex}}$ & $\mathrm{nF}_{\mathrm{EX}}-\mathrm{E}_{\mathrm{EX}}$ & $\mathrm{I}_{\mathrm{EX}}$ \\
\hline Total diatoms & $5.3 \pm 1.9$ & $0.3 \pm 0.4$ & $6.8 \pm 1.4$ & $1.7 \pm 0.7$ & $5.1 \pm 1.6$ \\
\hline NHAN & $-0.7 \pm 0.7$ & $-0.2 \pm 0.3$ & $0.2 \pm 0.6$ & $-0.3 \pm 0.2$ & $0.5 \pm 0.7$ \\
\hline ADMI & $3.9 \pm 0.8$ & $0.6 \pm 0.4$ & $3.5 \pm 0.5$ & $1.6 \pm 0.8$ & $1.8 \pm 0.9$ \\
\hline FCAP & $1.6 \pm 0.7$ & $-0.0 \pm 0.1$ & $2.5 \pm 0.4$ & $0.1 \pm 0.1$ & $2.4 \pm 0.4$ \\
\hline
\end{tabular}


Author-produced version of the article published in Freshwater Biology, 2012, vol. 57 (8), 1658-1666.

The original publication is available at http://onlinelibrary.wiley.com/doi/10.1111/j.1365-2427.2012.02827.x/abstract doi : 10.1111/j.1365-2427.2012.02827.x

\section{FIGURES}

507 Figure 1: Experimental set-up during exposure and recovery periods. Biofilms grown under

508 control conditions are in white (no $\mathrm{Cu}$ added in water) and under contaminated conditions in grey

509 (channels supplemented with $\mathrm{Cu}$ ).

511 Figure 2: Proportion of diatoms and relative abundance of the dominant diatom species and abnormal individuals over the course of the experiment. All data are expressed in \% (in the case of total diatoms, $\%$ of the total algal community).

Figure 3: Cluster analysis of the samples based on diatom species relative abundance. Only the taxa representing more than $1 \%$ relative abundance in at least one sample are taken into account. See Fig. 2 for abundance of the dominant species on each sampling date.

Figure 4: Mean rates of increase (in cell doublings/day) over the 6-week experimental period of the global diatom assemblage (Total diatoms), dominant species and abnormal cells. n.s.: non-

521 significant $(P>0.05)$. 
Author-produced version of the article published in Freshwater Biology, 2012, vol. 57 (8), 1658-1666.

The original publication is available at http://onlinelibrary.wiley.com/doi/10.1111/j.1365-2427.2012.02827.x/abstract doi : 10.1111/j.1365-2427.2012.02827.x

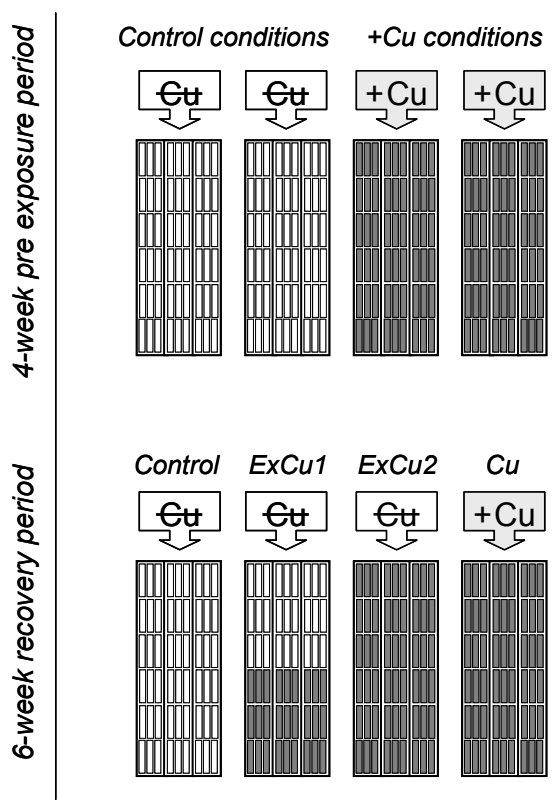

$524 \quad$ Fig. 1

525

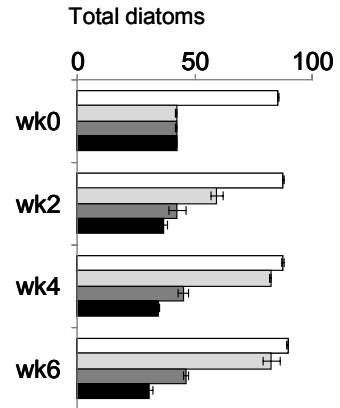

Nitzschia hantzschiana

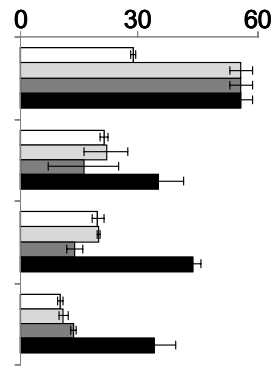

Achnanthidium minutissimum
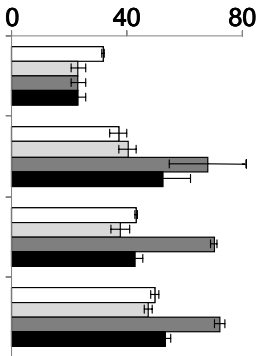

Fragilaria capucina

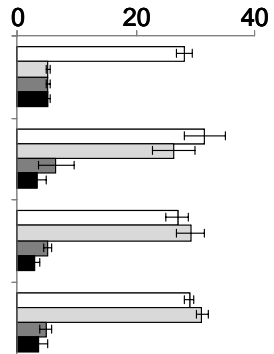

Abnormal diatom cells

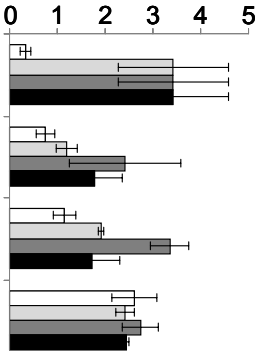

527 Fig. 2 
Author-produced version of the article published in Freshwater Biology, 2012, vol. 57 (8), 1658-1666.

The original publication is available at http://onlinelibrary.wiley.com/doi/10.1111/j.1365-2427.2012.02827.x/abstract doi : 10.1111/j.1365-2427.2012.02827.x

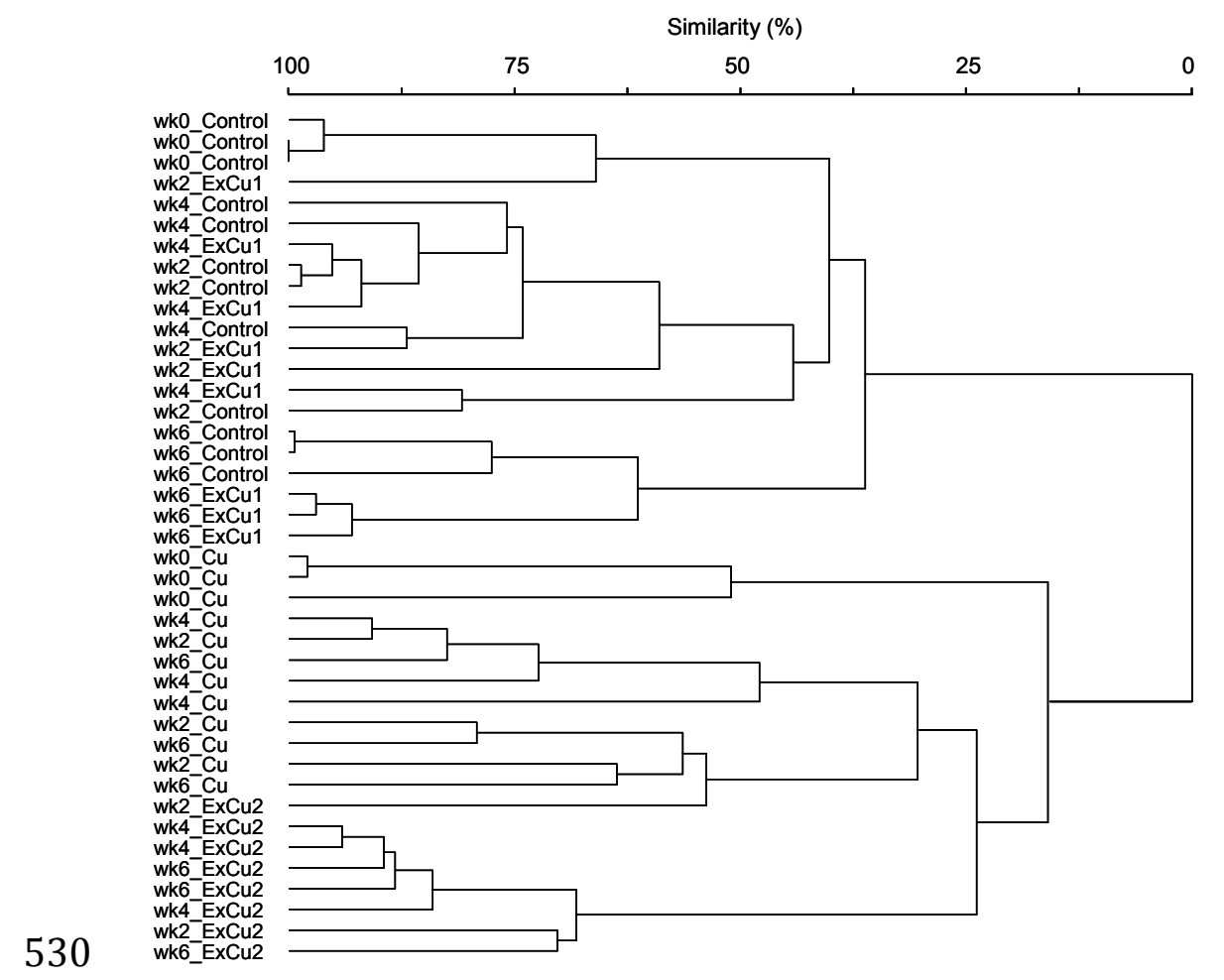

531 Fig. 3

532

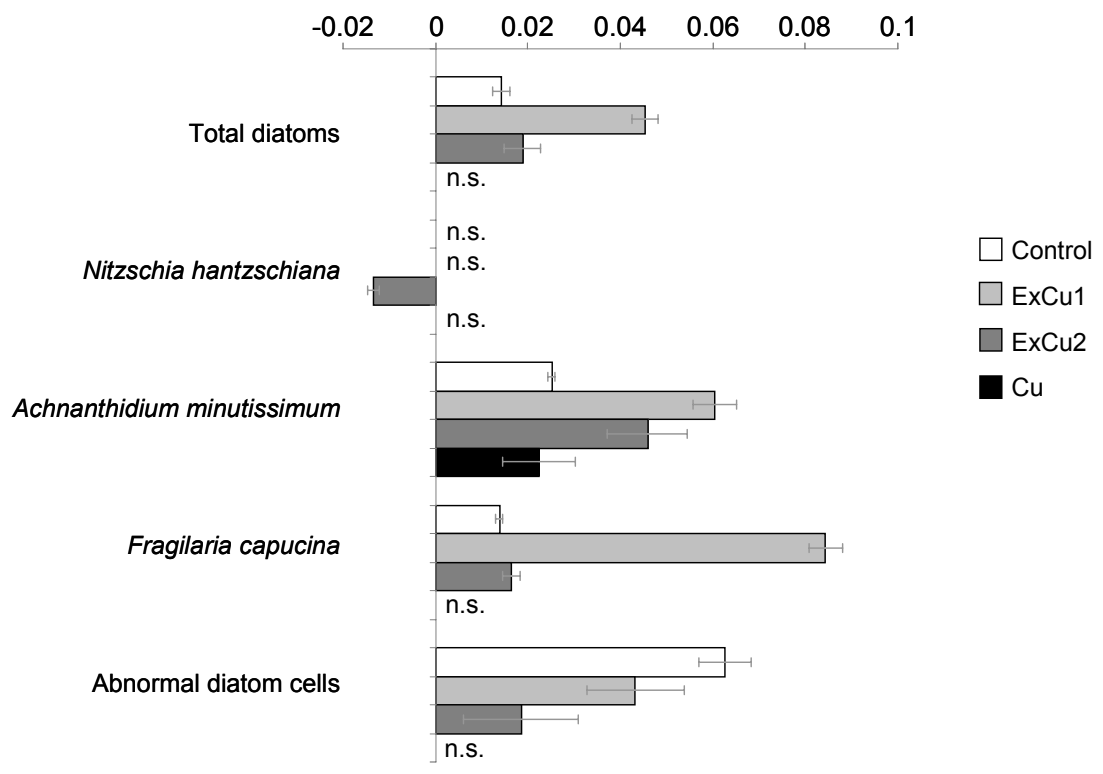

533

534 Fig. 4

535 